volume includes a section called "Reseñas de Jurisprudencia", which is a collection of abstracts of different decisions grouped under the common denominator of some specific, narrow aspect of labor law, e.g. "Confession as Evidence," "Documentary Evidence", etc.

This publication which is entirely written in Spanish is projected to appear five times a year and three issues have been already published. A cumulated, bound volume is supposed to appear at the end of each year. This cumulative volume will include parties, subject and jurisdiction indexes.

Considering the growing importance of labor law, these reports offer the opportunity of access to a body of case law that should be of extraordinary value not only to the scholar and the comparativist but also to the specialized practitioner as well. It should also be welcome in those libraries that serve a clientele capable of reading this material in its original language.

\author{
Jorge L. Carro \\ Professor of Law and Law Librarian \\ University of Cincinnati
}

\title{
DUTCH LAW LIBRARY BULLETIN
}

The inaugural issue of De Juridische Bibliothecaris (the Information Bulletin of the Dutch Group of Law Libraries and Legal Documentation Centers) was noted in the IALL Newsletter, No. 24, p. 2 (November 1979). In the meantime this new bulletin has commenced regular publication, and several issues have already made their appearance.

Each issue contains several short articles on different subjects pertaining to law librarianship and the retrieval of legal information, reports about the activities of Dutch law librarians, and extensive bibliographic lists of new publications. These lists should be useful to law librarians throughout the world. Meticulously compiled, they include not only references to new Dutch law books, but also to legal bibliographies published either in periodicals or as separate monographs in other countries. Articles and books on law librarianship are also listed irrespective of their place of publication. The lists are current and remarkably comprehensive. It is evident that the Dutch law librarians are well-informed about what gets published outside their country.

The editor-in-chief of De Juridische Bibliothecaris is Gert W. Vlasman, Law Librarian at the Catholic University in Tilsburg and an active member of the International Association of Law Libraries. Though the language of the publication is Dutch, it should present no difficulties to readers familiar with the English language. Two issues a year are published at the present time. The annual subscription is Dfl. 30. Subscriptions should be addressed to Mr. Gert W. Vlasman, Juridische Faculteit K. H. Tilburg, 5037 GC Tilburg, The Netherlands. 